\title{
Production of Lipids from Tunisian Wild Microalgae: Influence of Cell Disruption, Extraction Methods and UV-B Radiation Exposure
}

\author{
Ines Dahmen Ben Moussa*, Mohamed Bouaziz and Abdelhafidh Dhouib \\ Laboratory of Environmental Bioprocesses, University of Sfax. Sidi Mansour, Tunisia
}

Received: 㘹: September 16, 2018; Published: 㘹 October 01, 2018

*Corresponding author: Ines Dahmen Ben Moussa, Laboratory of Environmental Bioprocesses, Centre of Biotechnology of Sfax, University of Sfax. Sidi Mansour Road Km 6, PO Box «1177», 3018 Sfax, Tunisia, North Africa

\begin{abstract}
Identification of cost-effective methods of cell lysis and lipid extraction from microalgae represent a critical step in the determination of promising biodiesel-producing species. Several cell disruption methods were tested in the microalgae Amphora subtropica, Tetraselmis marina, Picochlorum sp. and Dunaliella sp. Among the methods tested, enhanced lipid extraction was achieved through microwave for Amphora biomass and osmotic shock for Tetraselmis, Picochlorum, and Dunaliella biomass. The Cequier-Sanchez method rendered the highest TL content in Amphora subtropica and Picochlorum sp. while Bligh and dyer method gave the highest TL content in Tetraselmis marina and Dunaliella sp. The treatment of microalgae with 5 days of UV-B stress led to a carotenoid and lipid content increase of 44,159, 116 and 150\%, respectively, and of 56, 84, 111 and $80 \%$, respectively, but with a reduction of the total chlorophyll content $(30,43,24$ and $34 \%$, respectively). Furthermore, a significant increase in malondialdehyde level and superoxide dismutase, catalase and glutathione peroxidase activities toward the control was recorded in response to UV stress. Overall results indicate that treatment of Amphora, Tetraselmis, Picochlorum and Dunaliella with UV-B radiation can further increase the total lipid production, due to its high percentage of SFA and MUFA can be potentially utilized for biodiesel production.

Abbreviations: AOS: Active Oxygen Species; BD: Bligh and Dyer Method; Car: Carotenoids; CAT: Catalase; Chl: Chlorophyll; DT: Direct TransEsterification; FA: Fatty Acid; FAME: Fatty Acid Methyl Ester; GPx: Glutathione Peroxidase; MDA: Malondialdehyde; MUFA: Monounsaturated Fatty Acids; NBT: Nitro Blue Tetrazolium; PUFA: Polyunsaturated Fatty Acids; SFA: Saturated Fatty Acids; SOD: Superoxide-Dismutase; TL: Total Lipid; UV: Ultraviolet Radiation
\end{abstract}

\section{Introduction}

Biodiesel is a renewable and clean energy source to reduce carbon dioxide and greenhouse gas emissions. The third generation of biodiesel feedstock, derived from algae, is recognised a being the most environmentally friendly and effective option. Microalgae are photosynthetic prokaryotic or eukaryotic microorganisms that can grow rapidly and live in difficult conditions due to their simple cell structure [1]. Microalgae uses solar energy, nutrients and carbon dioxide $\left(\mathrm{CO}_{2}\right)$ to produce proteins, carbohydrates, lipids and other valuable organic compounds like carotenoids $[2,3]$. The chemical compounds synthesized by microalgae have various applications. The lipids of microalgae have attracted attention as future feedstock for the synthesis of biodiesel, among others because of unique characteristics, i.e., shorter generation time, suitability of growing in culture vessels and open ponds, high CO2-sequestering capability, ability to grow in wastewater/seawater/brackishwater, non-interference of food chain, and high lipid productivity $[4,5]$.

Recovery of the microalgal biomass is a solid-liquid separation step in the production process. Except in cases where the algae are filamentous (Spirulina sp.) or form flocculates (Phormidium $s p$.). Biomass harvesting is difficult to achieve mainly because of the small size of organisms (typically less than $20 \mu \mathrm{m}$ ) and the need to treat large volumes of water [6]. The recent studies on microalgae mostly encompass extraction strategies that involve the selection of improved formula for solvents and the various disruptive techniques with focus on biodiesel production yield from specific oleaginous strains [7].Thus a variety of methods aiming at the disruption of the cell walls of whole microalgae have been investigated, including thermal, ultrasonic, microwave, chemical, mechanical, and other pretreatment [8]. Cell disruption enhances the release of intracellular lipids from microalgae by improving the access of the extracting solvent to fatty acids [9].

The extraction efficiency also depends on the species and the method of extraction used [10]. The lipid composition of various types of micro-algae such as diatoms [11], Nannochloropsis [12] and Phaeodactylum tricornutum [13] has been studied by many researchers. [14] studied different methods for extracting lipid: 
traditional solvent extraction, soxhlet extraction and supercritical $\mathrm{CO}_{2}$ extraction. The extraction with supercritical $\mathrm{CO}_{2}\left(\mathrm{scCO}_{2}\right)$ is suggested by some investigators in analogy to the production of fish oil. However, low yields show that $\mathrm{scCO}_{2}$ is not suitable for extracting microalgae lipid. Furthermore, the supercritical $\mathrm{CO}_{2}$ may extract only the neutral lipid fraction that is a minor part of the lipid fraction of microalgae. Solvent extraction is still the method of extraction used by many researchers because of its simplicity, relatively low cost and the lack of investment for equipment [15]. A comparison of different methods for extracting compounds for pharmaceutical importance from microalgae was conducted on Chlorella vulgaris [2], but no comparison was made with respect to extraction with the mixture of chloroform / methanol solvent.

Microalgae and cyanobacteria are characterized by their high metabolic plasticity and have a metabolic and physiological response to any combination of environmental factors: lightdark, hot-cold, aerobic-anaerobic, nutrient deficiency-excess, salinity ... etc. To increase the productivity of lipids in microalgae cells, application of UV stress is an effective method. This physical method is rapid, effective and safe to the environment [16]. Global UV-B radiation becomes stronger after the appearance of ozone hole in the Antarctic. UV-B radiation produces harmful effects on the physiological and morphological characteristics of plants and thus constitutes a serious threat to the existence and survival of organisms [17]. Previous studies have shown that UV-B decreases the growth rate and photosynthetic activity of $[18,19]$. Furthermore, it has been confirmed that UV-B radiations stimulates the formation of active oxygen species (AOS) at various sites of respiratory and photosynthetic electron transport as well as during different biochemical reactions in cellular systems [17].

Currently, microalgae have attracted attention for their capability to produce antioxidant compounds such as carotenoids [20]. These compounds play a key role against degenerative diseases and aging induced by free radicals the AOS. Unlike nutrient stress, UV stress increases the lipid peroxidation in microalgae [21]. To overcome the oxidative stress, microalgae have produced enzymatic and non-enzymatic antioxidants such as carotenoids that offer protection by scavenging harmful radical or oxygen species [17]. Carotenoids protect cells against photo-oxidative damage by absorbing triplet state energy from chlorophyll and quenching singlet state oxygen while $\alpha$-tocopherol prevents lipid peroxidation by scavenging AOS [22]. The enzymatic antioxidants include superoxde dismutase (SOD), catalase (CAT), glutathione peroxidase (GPx) and the enzymes involved in the ascorbate-glutathione cycle to detoxify AOS [23].

According to numerous reports in the literature about cell disruption and lipid extraction from microalgae biomass, the method's efficiency depends on the species studied. But due to small number of studies with comparative analysis between these different methods, there have no reports of the most efficient method of cell disruption and lipid extraction from Amphora subtropica, Tetraselmis marina, Picochlorum sp. and Dunaliella sp. This work for the first part aims to compare various cell disruption and lipid extraction techniques and identify the best of these according to efficiency criteria based on lipid content of four microalgae, Amphora subtropica, Tetraselmis marina, Picochlorum sp. and Dunaliella $s p$. Finally, the conversion of lipids to fatty acid mthyle ester (FAME) was performed to determine fatty acid distribution after extraction. In the second part, an attempt has been made to study the effects of UV-B radiation on the growth, photosynthetic pigments, lipid content and composition, antioxidant enzymes and lipid peroxidation in Amphora subtropica, Tetraselmis marina, Picochlorum sp. and Dunaliella sp.

\section{Material and Methods}

\section{Microalgal Cultivation}

Four microalgal samples representing different order Amphora subtropica (Bacillariophyceae), Tetraselmis marina (Chlorodendrophyceae), Picochlorum sp. and Dunaliella sp. (Chlamydomonadales) were used as the representative genera, because these strains present high growth rates and can produce large quantities of lipids [24-27]. Microalgae were isolated from saline water Port of Sfax, saline water Petit Paris, Kelibia, the Mediterranean coast in the region of Sidi Mansour, Sfax and hyper saline water Chott El-Jerid, Touzeur, Tunisia. Microalgae cultures were grown under standardized laboratory conditions in $1 \mathrm{~L}$ conical flasks at temperature: $26^{\circ} \mathrm{C}$, photon flux: $80 \mu \mathrm{mol} \mathrm{m}{ }^{-2}$ $\mathrm{s}^{-1}$ and photoperiod: 24:0 $\mathrm{h}$ light dark cycle. The inoculums were transferred to 15-Lglass air bubble photobioreactor (Isotherm, Germany) containing $8 \mathrm{~L}$ fresh optimized F/2 culture medium. Salinity concentration was $40 \pm 1 \%$ or $140 \%$ for Dunaliella $s p$. Microalgae cultures were assessed for 10 days and was carried out under the same previously conditions and aerated continuously $(0.03 \mathrm{vvm})$ with filtered $(0.22 \mu \mathrm{m})$ air. Cells were gently harvested by centrifuging at $6000 \times \mathrm{g}, 3 \mathrm{~min}$ and the obtained pellets were then frozen, and stored at $-80^{\circ} \mathrm{C}$ prior to analysis.

\section{Cell Disruption for Lipid Extraction}

An aliquot $(1 \mathrm{~g})$ of the wet cell biomass was frozen overnight at $-80^{\circ} \mathrm{C}$ and disrupted by means of different cell disruption methods: Osmotic Shock using 10\% NaCl solution for Amphora subtropica, Tetraselmis marina and Picochlorum sp. or $0 \% \mathrm{NaCl}$ solution for Dunaliella $s p$. and vortexing for 2 min followed by a 48-h incubation at room temperature; Microwave treatment oven at a high temperature $\left(100^{\circ} \mathrm{C}\right.$ and $\left.2450 \mathrm{MHz}\right)$ for $2 \mathrm{~min}$; lyophilisation treatment for 1 day; water bath by taking biomass in a $15-\mathrm{mL}$ centrifuge tube and placing in preheated water bath for $20 \mathrm{~min}$ at 60,80 and $105^{\circ} \mathrm{C}$ to induce the thermolysis. After each treatment, lipid extraction from microalgae was done according to [28]. After centrifugation $(4000 \times \mathrm{g}$ for $2 \mathrm{~min}$ ), the upper layer was collected and dried under nitrogen gas. Lipid content (\% dry weight basis) was determined gravimetrically.

\section{Quantifying Cell Disruption}

The effectiveness of each treatment was quantified by measuring the fraction of physically disrupted cells by counting the number of intact cells treated against those initially determined from the control values. The total cell disruption (D) was quantified in terms of the ratio of the average number of intact cells counted 
after each disruption method (Id) to the initial counts of intact cells before disruption treatment (I0). D then, is given by

$$
\mathrm{D}=\left(1-\mathrm{I}_{-} \mathrm{d} / \mathrm{I}_{-} 0\right) \times 100
$$

Where the ratio Id/I0 indicates the cell survival probability.

\section{Lipids Extraction}

The lipid fraction was extracted by the method of:

a) [29] (chloroform /methanol / water = 1:2:0,8,v/v);

b) [28] (chloroform / methanol / hexane = 2: 1: 0,5 and, v/v);

c) [30] (dichloromethane $/$ methanol = 3:2 v/v);

d) [31] Hexane/isopropanol (3 :2);

e) [32] (methanol / Diethyl ether / hexane / water).

All solvents were purchased from Sigma-Aldrich (St. Louis, MO) and were HPLC grade. Only glass containers were used for organic solvent handling to prevent contamination. All extractions were performed in triplicate, using samples of $1 \mathrm{~g}$ wet weight algal biomass. After extraction, the organic phase is then dried under a nitrogen stream and the extracted lipids were stored at $-20^{\circ} \mathrm{C}$ until being transesterified and analyzed by GS-MS.

\section{Trans-Esterification and Quantification of Fatty Acid Methyl Esters}

Trans-esterification of the crude lipid was performed using the protocol described by Li-Beisson (2010). Oil were dissolved in $1 \mathrm{~mL}$

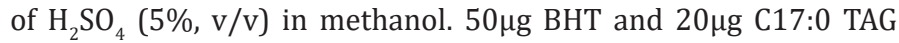
(triheptadecanoin) as internal standard were added to lipid extract and the samples mixed briefly by vortexing before was incubated at $85^{\circ} \mathrm{C}$ for $90 \mathrm{~min}$. After the reaction was completed, the samples were cooled to room temperature, mixed with $1 \mathrm{~mL}$ hexane, and time allowed for phase separation. The lower phase containing FAME was collected and transferred to a glass test tube. Direct trans-esterification without prior extraction was also performed. For this, $15 \pm 0.3 \mathrm{mg}$ lyophilized biomass powder was used and was transesterified directly by following the procedure given above [33].

The FAME extract was redissolved in $500 \mu \mathrm{L}$ hexane. The analysis of FAME was performed in GC-MS HP model 5975B inert MSD (Agilent Technologies, J\&W Scientific Products, Palo Alto, CA, USA), equipped with an Agilent Technologies capillary DB-5MS column ( $30 \mathrm{~m}$ length; $0.25 \mathrm{~mm}$ i.d.; $0.25 \mathrm{~mm}$ film thickness), and coupled to a mass selective detector (MSD5975B, ionization voltage $70 \mathrm{eV}$; all Agilent, Santa Clara, CA). The carrier gas was He and was used at $1 \mathrm{~mL}$ min- 1 flow rate. The oven temperature program was: $1 \mathrm{~min}$ at $100^{\circ} \mathrm{C}$ ramped from 100 to $260^{\circ} \mathrm{C}$ at $4^{\circ} \mathrm{C}$ min- 1 and $10 \mathrm{~min}$ at $260^{\circ} \mathrm{C}$. The chromatograph was equipped with a split/ splitless injector used in the split mode. The split ratio was 1:100. Identification of components was assigned by matching their mass spectra with Wiley and NIST library data.

\section{UV-B Treatment}

Effect of UV-B radiation on growth, biomass productivity, lipid content and productivity, fatty acid profile, AOS and pigment accumulation by Amphora subtropica, Tetraselmis marina and Picochlorum sp. and Dunaliella sp., were tested by transferring the microalgae adopted at their phase of exponential growth $\left(7^{\text {th }}\right.$ day of the batch culture), after centrifugation at $4000 \times \mathrm{g}$, into a fresh F/2 Provasoli (so that the nutriments were present in non-limiting quantities). Microalgae were exposed to $0.28 \mathrm{~W} \mathrm{~m}^{-2}$ of UV-B radiation for 5 days. The controls were grown under the same conditions as those used before UV stress $\left(80 \mu \mathrm{mol}\right.$ photons $\mathrm{m}^{-2} \mathrm{~s}^{-1}, 24: 0 \mathrm{~h}$ light/ dark cycle, $26^{\circ} \mathrm{C}$ ). Each experiment was repeated three times.

\section{Determination of Dry Matter, Biomass and Lipid Productivities and Photosynthetic Pigments}

Microalgal growth was monitored daily by measuring the dry cell weight (DCW) $\left(\mathrm{mg} \mathrm{L}^{-1}\right)$. The biomass productivity (BP) are the presented values an average for the 5 days and was calculated according to equation BP $\left(\mathrm{mg} \mathrm{L}^{-1} \mathrm{day}^{-1}\right)=(\mathrm{X} 2-\mathrm{X} 1) /(\mathrm{t} 2-\mathrm{t} 1)$, where, $\mathrm{X} 2$ and $\mathrm{X} 1$ are the dry cell weight (DCW) $\left(\mathrm{mg} \mathrm{L}^{-1}\right)$ at time $\mathrm{t} 2$ and t1, respectively. Lipid productivity (LP) is calculated as the product of the lipid content and the BP. Cells were removed by means of centrifugation $\left(4,000 \times \mathrm{g}\right.$ at $\left.4^{\circ} \mathrm{C}\right)$. The pellet was washed twice with distilled water and was analyzed for photosynthetic pigments content as described by [33] using the DMSO.

\section{Malondialdehyde (MDA) Measurement and Antioxidant Enzymes Assay}

Thiobarbituric acid reactive substances production in test samples was measured after 5th day of UV-B treatment by the method of Draper and Hadley [34]. The total (Cu-Zn and $\mathrm{Mn}$ ) superoxide-dismutase (SOD) activity was assayed by measuring its ability to inhibit the photoreduction of nitroblue tetrazolium (NBT). SOD activity was expressed as units per milligram of proteins (U $\mathrm{mg}^{-1}$ protein). Catalase (CAT) activity was measured according to Aebi (Aebi 1984). The enzyme activity was expressed as $\mu$ mol $\mathrm{H}_{2} \mathrm{O}_{2}$ destroyed $\mathrm{min}^{-1} \mathrm{mg}^{-1}$ protein. Glutathione peroxidase (GPx) activity was determined by the method of [35]. The enzyme activity was expressed as $\mu \mathrm{mol}$ of GSH oxidized $\mathrm{min}^{-1} \mathrm{mg}^{-1}$ protein.

\section{Statistical Analysis}

Data were presented as means \pm SD. One-way analysis of variance (ANOVA) was performed to identify statistically significant differences in data sets at a 95\% confidence level $(p<0.05)$.

\section{Results and Discussion}

\section{Effect of Pretreatment of Biomass on The Lipid Extraction and Fatty Acid Composition}

Cell disruption breaks the cells and improves the accessibility to the intracellular components for extraction [36]. Six methods were evaluated to understand the efficiency of cell disruption methods for total lipid extraction from Amphora subtropica, Tetraselmis marina, Picochlorum sp. and Dunaliella sp. The effectiveness of the cell disruption methods was determined using lipid yield percentages (Figure 1). All the cell disruption methods used in this study were able to disrupt microalgae cells, although lipid yield varied. In the present investigation, lipid extraction after osmotic shock-pretreated microalgae generated high yields. Osmotic shock of cell disruption for lipid extraction was found to be most efficient 
for Tetraselmis marina, Dunaliella sp. and Picochlorum sp. with highest values of 361,376 and $240 \mathrm{~g} \mathrm{~kg}^{-1}(\mathrm{p}<0.05)$ (Figure 1).

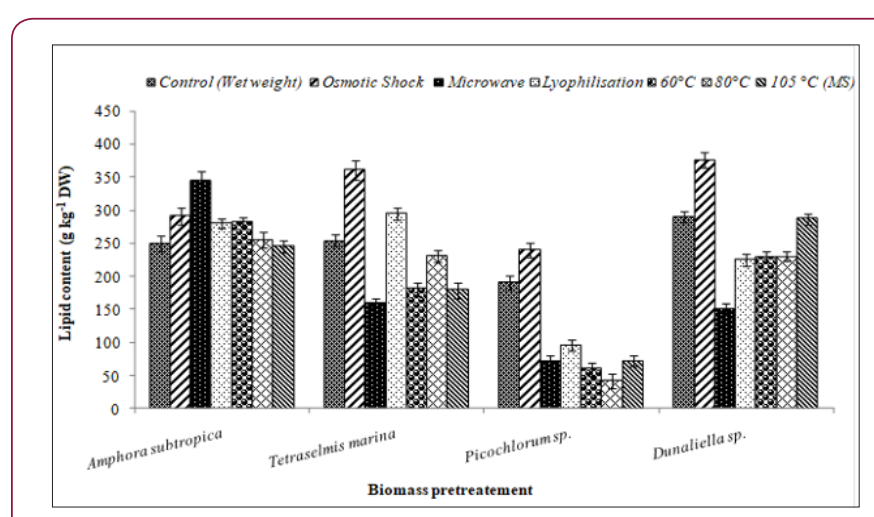

Figure 1.

However, microwave method was more efficient for Amphora subtropica $\left(345 \mathrm{~g} \mathrm{~kg}^{-1}\right)$ in 7 th day old cultures because of the presence of several micro-cracks in the cell wall. Microwave technology has allowed the development of rapid, safe, and economical methods for extracting lipids and does not require dewatering of algal biomass [10]. In addition, [10] increased the yield of lipid extraction of microalgae Botryococcus sp. in aqueous phase from 88 to $286 \mathrm{~g}$ $\mathrm{kg}^{-1} \mathrm{DW}$ by changing the ultrasonic process by the microwave. Lysis after lyophilization also significantly $(\mathrm{p}<0.05)$ enhanced the lipid content in microalgae Amphora subtropica and Tetraselmis marina to 283 and $295 \mathrm{~g} \mathrm{~kg}^{-1}$, respectively, in comparison with control condition (250 and $254 \mathrm{~g} \mathrm{~kg}^{-1}$, respectively). Indeed, it is the most popular method for extracting lipids in laboratory scale [10].

Heating at both $60^{\circ} \mathrm{C}$ and $80^{\circ} \mathrm{C}$ resulted in a slight decrease of lipid content for Tetraselmis marina and Dunaliella sp., but when heating was conducted at $105^{\circ} \mathrm{C}$, the lipid content decreased significantly. Indeed, drying is an energetic and very expensive operation in industrial processes therefore uneconomic [37]. For example, life cycle analysis conducted on the process of biodiesel production from microalgae indicates that $90 \%$ of the process energy is consumed by oil extraction, indicating that any improvement in lipid extraction will have a significant impact on the economics of the process [37]. It is therefore important to move towards the use of wet algal biomass in the extraction processes. As an exception, drying the biomass Dunaliella sp. at $105^{\circ} \mathrm{C}$, led to extract a large amount of lipid. Our results show that for the other strains, the lipid content decreased when the temperature of drying the biomass was high $\left(80\right.$ and $\left.105^{\circ} \mathrm{C}\right)$. This agrees with results reported by [38].

Microscopic observations represented a qualitative approach to the success of the different cell disruption techniques. The determination of cell disruption values confirmed that the cellular disruption is affected by the different treatments on the intact cells (Figure 2). Figure 2 also shows that the significantly higher disruption values were attained in the microwave treatment for Amphora subtropica (90\%) and osmotic shock method for Tetraselmis marina (87\%), Dunaliella sp. (85\%) and Picochlorum sp. (75\%). Similarly, revealed a high percentage cell disruption in Nannochloropsis oculata after microwave treatment. These methods consume less energy than traditional methods. Osmotic shock method was implemented in Tetraselmis marina, Dunaliella and Picochlorum cell disruption and lipid extraction, to reduce the energy consumption and production cost. In fact, osmotic shock can disturb algal cell walls through a hasty increase and decrease in the salt concentration of the culture media; this can disturb the balance of osmotic pressure between the interior and exterior of the algal cells. According to some authors, positive results could be achieved by using the osmotic shock method for the extraction of oil from various microalgal biomasses such as those of Chlamydomonas reinhardtii [37], Botryococcus sp., Chlorella vulgaris, and Scenedesmus sp. [39], Botryococcus sp. MCC32 and Chlorella sorokiniana MIC-G5 [40].

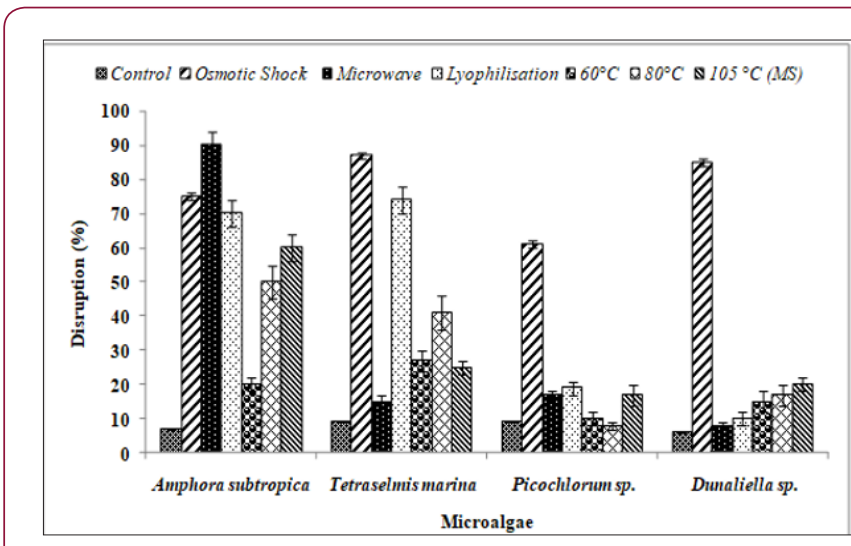

Figure 2.

Thus, it was concluded that the osmotic pressure method would appear to be the most simple, easy, and efficient method $[39,41]$. Due to differences in cell wall structure, not all microalgae respond the same to pretreatment. For example, [10] observed that microwave treatment was optimum for the disruption of Botryococcus sp., Chlorella vulgaris and Scenedesmus sp. cells. Available literature suggests that cell disruption methods improve lipid extraction from microalgae, it depends on microalgae species, age of the culture and composition of cell wall. Therefore, results obtained from one species cannot be generalised to all other species [15]. A recent study by [42,40] presented that the osmotic shock (Os) and microwave (Mw) treatments were most suitable methods in extracting intracellular products, which can also be industrially scaled up.

The fatty acid profiles of the lipids extracted following different cell disruption methods from Amphora subtropica (Mw), Tetraselmis marina, Picochlorum sp. and Dunaliella sp. (Os), are presented in Table 1. Major fatty acids such as palmitic acid (31.95\%), palmitoleic acid (21.57\%) and oleic acid (14.62\%) were detected in Amphora subtropica based on Microwave cell disruption. Total saturated, monounsaturated and polyunsaturated fatty acid contents of Microwave method were 45.24\%, 40.19\% and $14.57 \%$, respectively, making it a potential feedstock for biodiesel production (Table 1). Likewise, in Tetraselmis marina, palmitic acid (46.6\%) palmitoleic acid (13.56\%) and oleic acid (26.89\%) were the major fatty acids (Table 1), with lower proportion of polyunsaturated fatty acids of $6.14 \%$, when cells were disrupted 
using osmotic shock, as comparing with control condition. Oleic acid was higher in Tetraselmis marina, when used with osmotic shock as cell disruption technique before lipid extraction (Table 1), as was observed by [10]. It is generally accepted that oils with high oleic acid content possess a reasonable balance of fuel properties [43].

Table 1: Comparison of the most promising cell disruption pretreatments, in terms of fatty acids composition of microalgae.

\begin{tabular}{|c|c|c|c|c|c|c|c|c|}
\hline \multirow[t]{2}{*}{ FA \% } & \multicolumn{2}{|c|}{ Amphora subtropica } & \multicolumn{2}{|c|}{ Tetraselmis marina } & \multicolumn{2}{|c|}{ Piccochlorum sp. } & \multicolumn{2}{|c|}{ Dunaliella sp. } \\
\hline & Control & Mw & Control & Os & Control & Os & Control & Os \\
\hline C14:0 & 6.61 & 8.64 & 2.36 & 2.51 & 2.25 & 2.23 & & \\
\hline $\mathrm{C} 16: 0$ & 24.71 & 31.95 & 50.80 & 46.6 & 28.57 & 29.33 & 33.62 & 31.41 \\
\hline C16:1 & 26.30 & 25.57 & 11.60 & 13.56 & 0.98 & 5.87 & - & 8.97 \\
\hline $\mathrm{C} 16: 2$ & - & - & - & - & 8.20 & 8.10 & - & - \\
\hline C16:3 & 24.23 & 1.75 & - & - & 11.00 & 8.80 & - & - \\
\hline C18:0 & 4.37 & 4.31 & - & 4.06 & - & 4.00 & - & - \\
\hline C18:1 & 4.14 & 14.62 & 21.56 & 26.89 & - & - & 5.1 & 17.38 \\
\hline C18:2 & 1.60 & 2.71 & 7.74 & 2.77 & 22.00 & 19.80 & 18 & 11.1 \\
\hline C18:3 & - & 0.85 & 3.15 & 1.78 & 27.00 & 21.87 & 43.28 & 15.21 \\
\hline $\mathrm{C} 20: 0$ & - & 0.34 & - & 0.24 & - & - & - & 7.52 \\
\hline $\mathrm{C} 20: 1$ & - & - & - & - & - & - & - & 5.29 \\
\hline $\mathrm{C} 20: 4$ & 3.86 & 4.2 & 1.50 & 0.54 & - & - & - & - \\
\hline C20:5 & 4.19 & 5.06 & 1.30 & 1.05 & - & - & - & - \\
\hline $\mathrm{C} 22: 0$ & - & - & - & - & - & - & - & 3.12 \\
\hline SFA & 35.69 & 45.24 & 53.16 & 53.41 & 30.82 & 35.56 & 33.62 & 42.05 \\
\hline UFA & 64.31 & 54.76 & 46.84 & 46.59 & 69.18 & 64.44 & 66.38 & 57.95 \\
\hline MUFA & 30.43 & 40.19 & 33.16 & 40.45 & 0.98 & 5.87 & 5.10 & 31.64 \\
\hline PUFA & 33.88 & 14.57 & 13.69 & 6.14 & 68.20 & 58.57 & 61.28 & 26.31 \\
\hline
\end{tabular}

FA: Fatty acid; Mw: microwave; Os: Osmotic shock; SFA: saturated fatty acid; UFA: unsaturated fatty acid; MUFA: monounsaturated fatty acid; PUFA: polyunsaturated fatty acid.

The osmotic shock method not showed significant differences for the fatty acid profile of Picochlorum sp. However, in Dunaliella $s p$., the total fatty acid composition with osmotic shock $(0 \% \mathrm{NaCl})$ as pretreatment resulted in total polyunsaturated fatty acid contents of $26.31 \%$, which was two-folds lower than control $(61.68 \%)$, without any pretreatment.

\section{Effect of Extraction Methods on The Lipid Content and}

\section{Fatty Acid Composition}

The toxicity of chloroform and methanol make Folch method unsuitable for large-scale extraction, which also makes it essential to compare the efficiencies of other solvent systems. Even though it was reported to be ineffective for extracting Five methods for lipid extraction were evaluated in Amphora subtropica, Tetraselmis marina, Picochlorum sp. and Dunaliella sp. biomass: [28] (F: chloroform / methanol / hexane), Bligh and Dyer (BD: chloroform /methanol / water), [32] (B: methanol / Diethyl ether / hexane / water), [30] (CS: dichloromethane/methanol) and [10] (L: Hexane/ isopropanol). Figure 3 shows the comparative analysis of different lipid extraction methods in relation to the total lipid content in the dry biomass. The efficiency of extraction of total lipids also varies by microalgal species. Among the tested methods, CequierSanchez method was the most efficient for Amphora subtropica and Picochlorum sp., obtaining approximately 35\% and $22.6 \%$ of total lipids, respectively, while that of Bligh and Dyer gave the highest yield of total lipids in the strain Tetraselmis marina (32\%) and Dunaliella sp. (35.2\%) directly applied after osmotic shock treatment. As expected, Dunaliella sp. reported the highest total fatty acids (TFA) content followed by Tetraselmis marina (Figure 3). The higher FA recoveries reported by DT method as compared with conventional methods (B and L in Tetraselmis marina, Picochlorum $s p$. and Dunaliella $s p$. and CS in Tetraselmis marina) prior to transmethylation can be explained by incomplete conversion of lipids to FAME and need further modifications for optimizing the yield, unfortunately this factor has not been the part of the present study.

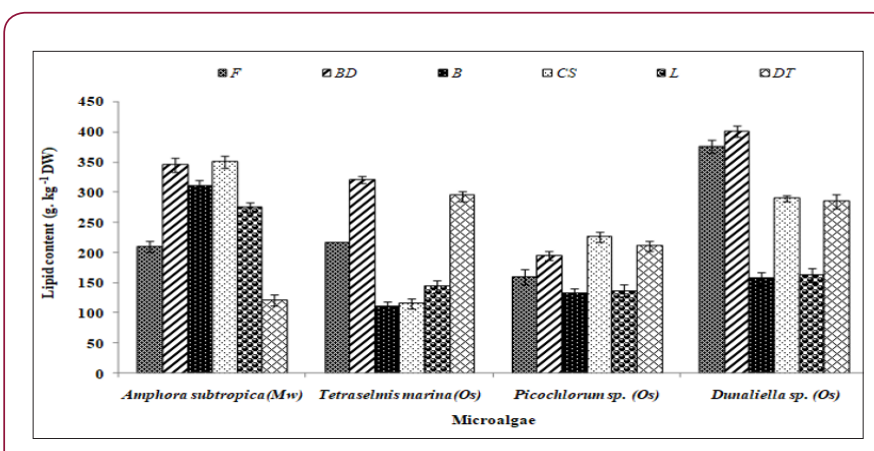

Figure 3.

The highest efficiency of both [30] and [29] methods can be due to two effects: the solvent nature and the effect of convection. 
The solvents used in [30] and [29], dichloromethane, methanol and chloroform, have a much higher capability to solubilize both neutral and polar lipids as compared to other less polar solvents mixtures as e.g. hexane and isopropanol [44]. Furthermore, the effect of convection, caused during extraction when using a steel disperser, produces a transient cavitation, which can affect the size and structure of the cell matrix therefore increasing lipid extractability. Interestingly, the extraction carried out by different methods can lead to great differences not only in the total extracted lipid, but also in their composition (Table 2). After having identified the best extraction method among those evaluated, Amphora subtropica and Picochlorum sp. samples were extracted by using Cequier-Sanchez method while Tetraselmis marina and Dunaliella sp. samples were extracted by using Bligh and Dyer method and then subjected to transmethylation to determine FA composition. The highest level of SFA\% (56.35\%) was found in Tetraselmis marina followed by $52.37 \%$ in Amphora subtropica and $45.69 \%$ in Dunaliella sp. The application of BD method in both Tetraselmis marina and Dunaliella and that of CS in both Amphora subtropica and Picochlorum extract increased the percentage of SFA and MUFA and considerably decreased the percentage of PUFA compared to the control [28] (Table 2). The present study displayed significant variations in lipid and fatty acid contents, owing to the matrix effect and solubilising ability of different solvent systems employed to further disrupt the cellular membranes and dissolve the entrapped lipid from microalgae. Similar results were reported by many researchers in plant [44], macroalgae [45], microalgae [15] and thus employing different lipid extraction methods for obtaining the best results.

Table 2: Comparison of the most promising lipid extraction methods, in terms of fatty acids composition of microalgae.

\begin{tabular}{|c|c|c|c|c|c|c|c|c|}
\hline \multirow[t]{2}{*}{ FA \% } & \multicolumn{2}{|c|}{ Amphora subtropica (Mo) } & \multicolumn{2}{|c|}{ Tetraselmis marina (0s) } & \multicolumn{2}{|c|}{ Picochlorum sp. (Os) } & \multicolumn{2}{|c|}{ Dunaliella sp (0s) } \\
\hline & Control (F) & CS & Control (F) & BD & Control (F) & CS & Control (F) & BD \\
\hline C14:0 & 8.64 & 10.24 & 2.51 & 1.41 & 2.23 & 3.46 & - & 2.66 \\
\hline C16:0 & 31.95 & 34.87 & 46.6 & 47.8 & 29.33 & 31.25 & 31.41 & 38.5 \\
\hline C16:1 & 25.57 & 36.95 & 13.56 & 12.56 & 5.87 & 12.59 & 8.97 & 5.71 \\
\hline C16:2 & - & - & - & & 8.10 & 9.1 & - & \\
\hline C16:3 & 1.75 & 1.22 & - & & 8.80 & 10.6 & - & \\
\hline C18:0 & 4.31 & 7.03 & 4.06 & 6.11 & 4.00 & 5 & - & 1.04 \\
\hline C18:1 & 14.62 & 1.47 & 26.89 & 27 & - & & 17.38 & 26.17 \\
\hline C18:2 & 2.71 & 2.55 & 2.77 & 0.18 & 19.80 & 11.43 & 11.1 & 12.7 \\
\hline C18:3 & 0.85 & 1.57 & 1.78 & 2.25 & 21.87 & 15.27 & 15.21 & 7.2 \\
\hline C20:0 & 0.34 & - & 0.24 & 0.31 & - & - & 7.52 & 3.49 \\
\hline C20:1 & - & & - & 1.39 & - & - & 5.29 & 2.53 \\
\hline C20:3 & - & & - & & - & - & - & \\
\hline C20:4 & 4.2 & 2.02 & 0.54 & 0.24 & - & - & - & \\
\hline C20:5 & 5.06 & 1.85 & 1.05 & 0.03 & - & & - & \\
\hline C22:0 & - & - & - & & - & - & 3.12 & \\
\hline C22:1 & - & & - & & - & 1.3 & - & \\
\hline $\mathrm{C} 24: 0$ & - & 0.23 & - & 0.72 & - & & - & \\
\hline SFA & 45.24 & 52.37 & 53.41 & 56.35 & 35.56 & 39.71 & 42.05 & 45.69 \\
\hline UFA & 54.76 & 47.63 & 46.59 & 43.65 & 64.44 & 60.29 & 57.95 & 54.31 \\
\hline MUFA & 40.19 & 38.42 & 40.45 & 40.95 & 5.87 & 13.89 & 31.64 & 34.41 \\
\hline PUFA & 14.57 & 9.21 & 6.14 & 2.7 & 58.57 & 46.4 & 26.31 & 19.9 \\
\hline
\end{tabular}

FA: Fatty acid; Mw: Microwave; Os: Osmotic shock; F: Folch et al. (1957) method; CS: Cequier-Sanchez (2008) method; BD: Bligh and Dyer (1959) method; SFA: Saturated fatty acid; UFA: Unsaturated fatty acid; MUFA: Monounsaturated fatty acid; PUFA: Polyunsaturated fatty acid.

Effect of UV-B Stress on the Growth, Photosynthetic Pigments, Lipids Content and Fatty Acid Composition

The final part of this study measured the effects of UV exposure on growth, photosynthetic pigments, lipid content and fatty acid methyl ester (FAME) composition. The growth responses of four tested microalgae Amphora subtropica, Tetraselmis marina, Picochlorum sp. and Dunaliella $s p$. to UV-B were inhibitory and the effect varied with microalgae strains. The cell dry weight for Amphora subtropica after UV-B was decreased by $57.3 \%$ relative to the control after 5 days of stress treatment. The corresponding values for Tetraselmis marina, Picochlorum sp. and Dunaliella $s p$. under the same experimental condition were 65.9, 72.7 and $76.4 \%$, respectively. Therefore, biomass productivities of Amphora subtropica and Tetraselmis marina were markedly lower than Picochlorum sp. and Dunaliella sp. The growth responses of these microalgae to UV-B stress showed considerable differences probably due to different degree of damage caused by UV-B directly or indirectly on DNA, proteins and photosynthetic apparatus [17]. 
UV-B radiation has been reported to impair the ultrastructure of microalgae [19].

In fact, it is well documented that, when cells are exposed to oxidative stress, the antioxidant systems can be potentiated to protect cells from free radical damages. Application of the above stress condition during the stationary growth phase increased the total carotenoids content in Amphora subtropica, Tetraselmis marina, Picochlorum sp. and Dunaliella sp. However, content of chlorophyll $a$ and chlorophyll $b$, the ratio $\mathrm{Chl} a / \mathrm{Chl} b$ and $\mathrm{Chl} a /$ Car reduced considerably following UV-B exposure. The possible explanation is that the bleaching caused by UV radiation directly activates oxygen- mediated peroxidation, indirectly resulting in damage to the photosynthetic pigments [18]. It is generally recognized that UV degrades photosynthetic pigment and proteins of chloroplasts, especially the D1 protein of the photosystem II (PSII), which is involved in the mechanisms of photosynthesis [46,47]. In the present study, UV-B induced damaging response photosynthetic pigments in these microalgae varied significantly. Low level of cell damage in this investigation can be explained by the accumulation of carotenoids in response to UV-B stress. Carotenoids have been found to be effective at protecting the photosynthetic apparatus against UV-B [44]. Our results imply that UV-B induced-damage is likely a dynamic balance between damage and adaptation, as has been proposed in previous studies $[17,48,49]$.

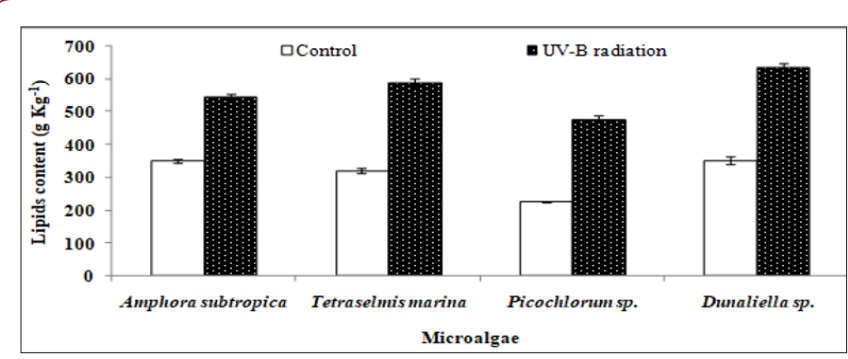

Figure 4: Effect of UV-B radiation on the cellular lipid content in the second stage of cultivation of Amphora subtropica, Tetraselmis marina, Picochlorum sp. and Dunaliella sp. Values are the means \pm SD. osmotic shock. The data represent means $\pm S D$.

As can be seen in Figure 4, the UV-B exposure increases the cell lipid content. In the absence of any stress condition, Amphora subtropica, Tetraselmis marina, Picochlorum sp. and Dunaliella sp. were shown to contain only 350,320, 226 and $352 \mathrm{~g} \mathrm{~kg}^{-1}$, respectively. In all studied microalgae, the cell lipid content showed a significant increase of $56 \%, 84 \%, 111 \%$ and $80 \%$, respectively, after 5 days of

Table 3: Effect of UV-B radiation on Contents of the main fatty acid methyl esters (FAMEs) of Amphora subtropica, Tetraselmis marina, Picochlorum sp. and Dunaliella sp. lipid fraction referred to total FAMEs (g/100 g FAME).

\begin{tabular}{|c|c|c|c|c|c|c|c|c|}
\hline FA \% & \multicolumn{2}{|c|}{ Amphora subtropica } & \multicolumn{2}{|c|}{ Tetraselmis marina } & \multicolumn{2}{c|}{ Picochlorum sp. } & \multicolumn{2}{c|}{ Dunaliella sp } \\
\hline & Control & UV & Control & UV & Control & UV & Control & UV \\
\hline C14:0 & 10.24 & 12.7 & 1.41 & 9.2 & 3.46 & 3.54 & 2.66 & \\
\hline C16:0 & 34.87 & 40.5 & 47.8 & 39 & 31.25 & 39.84 & 38.5 & 41.4 \\
\hline C16:1 & 36.95 & 34.86 & 12.56 & & 12.59 & 2.29 & 5.71 & 5.9 \\
\hline C16:2 & - & & & & 9.1 & & & \\
\hline
\end{tabular}

Cite this article: Ines Dahmen Ben Moussa, Mohamed Bouaziz, Abdelhafidh Dhouib. Production of Lipids from Tunisian Wild Microalgae: Influence of Cell Disruption, Extraction Methods and UV-B Radiation Exposure. Biomed J Sci\&Tech Res 9(3)-2018. BJSTR. MS.ID.001814. DOI: 10.26717/ BJSTR.2018.09.001814. 


\begin{tabular}{|c|c|c|c|c|c|c|c|c|}
\hline C16:3 & 1.22 & & & & 10.6 & & & \\
\hline C18:0 & 7.03 & & 6.11 & 7.8 & 5 & 12.73 & 1.04 & 6.5 \\
\hline C18:1 & 1.47 & 10.1 & 27 & 36.4 & & 12.8 & 26.17 & 17.66 \\
\hline C18:2 & 2.55 & 0.7 & 2.77 & 0.18 & 19.80 & 11.43 & 11.1 & 12.7 \\
\hline 4 & 0.18 & 0.5 & 11.43 & 19.1 & 12.7 & 3.6 & 15.21 & 7.2 \\
\hline C18:3 & 1.57 & & 2.25 & 0.8 & 15.27 & 9.7 & 7.2 & 12.14 \\
\hline C20:0 & - & & 0.31 & 1.89 & - & & 3.49 & 1.8 \\
\hline C20:1 & & & 1.39 & 2.87 & - & & 2.53 & 1.4 \\
\hline C20:3 & & & & & - & & & \\
\hline C20:4 & 2.02 & 0.6 & 0.24 & & - & & & \\
\hline $\mathrm{C} 20: 5$ & 1.85 & 0.5 & 0.03 & & & & & \\
\hline C22:1 & - & & & & 1.3 & & & \\
\hline C24:0 & 0.23 & & 0.72 & 1.54 & - & & & 9.6 \\
\hline SFA & 52.37 & 53.20 & 56.35 & 59.43 & 39.71 & 56.11 & 45.69 & 59.30 \\
\hline UFA & 47.63 & 46.80 & 43.65 & 40.57 & 60.29 & 43.89 & 54.31 & 40.70 \\
\hline MUFA & 38.42 & 44.96 & 40.95 & 39.27 & 13.89 & 15.09 & 34.41 & 24.96 \\
\hline PUFA & 9.21 & 3.04 & 2.7 & 1.3 & 46.4 & 28.8 & 19.9 & 15.74 \\
\hline
\end{tabular}

FA: Fatty acid; UV: UV-B radiation; SFA: saturated fatty acid; UFA: unsaturated fatty acid; MUFA: monounsaturated fatty acid; PUFA: polyunsaturated fatty acid.

Effect Of UV-B Stress on the Lipid Peroxidation and Antioxidant Enzymes

UV-B radiation induced the formation of MDA indicating enhanced lipid peroxidation in microalgae (Table 4). The activity of antioxidant enzymes in microalgae such as SOD, CAT and GPX was also enhanced after UV-B exposure. Content of MDA increased by 55, 61, 141 and 153\% in Amphora subtropica, Picochlorum sp., Dunaliella sp. and Tetraselmis marina, respectively (Table 5). The activity of SOD, CAT and GPx increased by 29, 97 and $40 \%$ in Amphora subtropica, 95, 107 and 55\% in Tetraselmis marina, 36, 60 and 71\% in Picochlorum sp. and 146, 98 and 110\% in Dunaliella sp., respectively. In the present study UV-B treatment induced the lipid peroxidation of PUFA via oxidative damage which consequently affects the integrity of thylakoid and cellular membranes [23]. [21] observed an increase in MDA content in Spirulina platensis and Dunaliella salina following UV-B exposure. Once UV-B radiation reaches the inside the cell, it interacts with oxygen and other organic compounds to produce toxic AOS such as superoxide, hydroxyl radical or hydrogen peroxide finally resulting in oxidative stress and activation of several antioxidative enzymes such as SOD, CAT and GPx. High activity of these antioxidative enzymes in Amphora subtropica, Tetraselmis marina, Picochlorum sp. and Dunaliella sp. could be linked with stress tolerance efficiency. Earlier studies have also demonstrated the increased activity of these enzymes to UV-B exposure in cyanobacteria [17] and micro green algae Dunaliella salina [21,55-57].

Table 4: Effect of UV-B radiation on dry weight, biomass productivity, lipid yield and productivity and pigments composition of Amphora subtropica, Tetraselmis marina, Picochlorum sp. and Dunaliella sp.

\begin{tabular}{|c|c|c|c|c|c|c|c|c|}
\hline Pigments Composition & \multicolumn{2}{|c|}{ Amphora subtropica } & \multicolumn{2}{|c|}{ Tetraselmis marina } & \multicolumn{2}{|c|}{ Picochlorum sp. } & \multicolumn{2}{c|}{ Dunaliella sp. } \\
\hline & Control & UV & Control & UV & Control & UV & Control & UV \\
\hline DW & $850 \pm 14$ & $487 \pm 12^{*}$ & $940 \pm 18$ & $620 \pm 13^{*}$ & $1105 \pm 15$ & $804 \pm 13^{*}$ & $1400 \pm 11$ & $970 \pm 21^{*}$ \\
\hline BP & $170 \pm 4.1$ & $97.4 \pm 3.2^{*}$ & $188 \pm 3.5$ & $124 \pm 4.5^{*}$ & $221 \pm 4.2$ & $160.8 \pm 7.1^{*}$ & $280 \pm 3.2$ & $214 \pm 1.8^{*}$ \\
\hline Lipid yield & $350 \pm 12$ & $547 \pm 10^{*}$ & $320 \pm 9.7$ & $589 \pm 21^{*}$ & $226 \pm 8.9$ & $478 \pm 11^{*}$ & $352 \pm 11$ & $634 \pm 15^{*}$ \\
\hline LP & $59.5 \pm 0.7$ & $53.3 \pm 0.6^{*}$ & $60.2 \pm 0.8$ & $84.8 \pm 1.2^{*}$ & $49.9 \pm 0.7$ & $83.5 \pm 0.9^{*}$ & $98.6 \pm 1.7$ & $122.9 \pm 1^{*}$ \\
\hline Chl a (pg cell-1) & $11 \pm 0.9$ & $7.3 \pm 0.4^{*}$ & $24 \pm 1.5$ & $13 \pm 0.8^{*}$ & $16 \pm 0.8$ & $11 \pm 1.1^{*}$ & $22 \pm 2.7$ & $14 \pm 1.1^{*}$ \\
\hline Chl b (pg cell-1) & $13 \pm 1.2$ & $9.4 \pm 0.8^{*}$ & $29 \pm 2.2$ & $16.8 \pm 1.2^{*}$ & $21 \pm 2.3$ & $17 \pm 2.5^{*}$ & $28 \pm 1.5$ & $19 \pm 1.4^{*}$ \\
\hline Car (pg cell ${ }^{-1}$ ) & $1.8 \pm 0.2$ & $2.6 \pm 0.3^{*}$ & $2.2 \pm 0.8$ & $5.7 \pm 0.7^{*}$ & $3 \pm 0.5$ & $6.5 \pm 0.7^{*}$ & $4 \pm 0.2$ & $10 \pm 0.9^{*}$ \\
\hline Chl a/Chl b & $0.84 \pm 0.09$ & $0.77 \pm 0.1^{*}$ & $0.82 \pm 0.04$ & $0.77 \pm 0.06^{*}$ & $0.76 \pm 0.4$ & $0.64 \pm 0.05^{*}$ & $0.78 \pm 0.03$ & $0.73 \pm 0.05$ \\
\hline Chl a/Car & $6.11 \pm 0.5$ & $2.80 \pm 0.2^{*}$ & $10.91 \pm 0.9$ & $2.28 \pm 0.4^{*}$ & $5.33 \pm 0.9$ & $1.69 \pm 0.9^{*}$ & $5.5 \pm 0.21$ & $1.4 \pm 0.05^{*}$ \\
\hline
\end{tabular}

Data are shown as the mean \pm SD $(n=3)$.

The asterisks indicate significant differences with respect to the values of control cultures $(\mathrm{p}<0.05)$.

Cite this article: Ines Dahmen Ben Moussa, Mohamed Bouaziz, Abdelhafidh Dhouib. Production of Lipids from Tunisian Wild Microalgae: Influence of Cell Disruption, Extraction Methods and UV-B Radiation Exposure. Biomed J Sci\&Tech Res 9(3)-2018. BJSTR. MS.ID.001814. 
Table 5: Effect of UV-B radiation on antioxidant enzymes and lipid peroxidation in Amphora subtropica, Tetraselmis marina, Picochlorum sp. and Dunaliella sp.

\begin{tabular}{|c|c|c|c|c|c|c|c|c|c|}
\hline & & \multicolumn{2}{|c|}{ Amphora subtropica } & \multicolumn{2}{|c|}{ Tetraselmis marina } & \multicolumn{2}{|c|}{ Picochlorum sp. } & \multicolumn{2}{|c|}{ Dunaliella sp. } \\
\hline & & Control & UV & Control & UV & Control & UV & Control & UV \\
\hline & $\begin{array}{c}\text { SOD } \\
\text { (Umg-1 } \\
\text { protein) }\end{array}$ & $17.2 \pm 0.1$ & $22.3 \pm 0.2$ & $9.1 \pm 0.12$ & $17.8 \pm 0.8$ & $14.5 \pm 0.8$ & $19.8 \pm 1.2$ & $10.2 \pm 0.4$ & $25.1 \pm 1.5$ \\
\hline \multirow[t]{2}{*}{$\begin{array}{l}\text { Enzyme } \\
\text { activity }\end{array}$} & $\begin{array}{c}\text { CAT } \\
\left(\mu \mathrm{mol} \mathrm{H}_{2} \mathrm{O}_{2}\right. \\
\mathrm{min}^{-1} \mathrm{mg}^{-1} \\
\text { protein })\end{array}$ & $9.8 \pm 0.05$ & $19.4 \pm 0.1$ & $11.9 \pm 0.4$ & $24.7 \pm 0.2$ & $7.3 \pm 0.05$ & $11.7 \pm 0.6$ & $11.4 \pm 0.1$ & $22.6 \pm 0.9$ \\
\hline & $\begin{array}{c}\text { GPx } \\
(\mu \mathrm{mol} \mathrm{GSH} \\
\text { min }^{-1} \mathrm{mg}^{-1} \\
\text { protein })\end{array}$ & $13 \pm 0.1$ & $18.2 \pm 0.5$ & $9.8 \pm 0.2$ & $15.2 \pm 0.1$ & $8.4 \pm 0.04$ & $14.4 \pm 0.8$ & $6.4 \pm 0.14$ & $13.5 \pm 0.1$ \\
\hline $\begin{array}{l}\text { Lipid } \\
\text { peroxidation }\end{array}$ & $\begin{array}{c}\text { MDA } \\
\text { (nmol mg } \\
\text { protein) }\end{array}$ & $1.8 \pm 0.4$ & $2.8 \pm 0.02$ & $1.5 \pm 0.06$ & $3.8 \pm 0.03$ & $1.8 \pm 0.01$ & $2.9 \pm 0.05$ & $2.4 \pm 0.03$ & $5.8 \pm 0.05$ \\
\hline
\end{tabular}

Data are shown as the mean $\pm S D(n=3)$.

\section{Conclusion}

The strain improvement has been considered as having an impact on the cost issues on microalgae lipid extraction. This comparative study enables us to test the efficiency of different method for cell disruption and lipid extraction in different microalgal species. Microwave improved the cell disruption efficiency, leading to increase in the lipid content in Amphora subtropica while osmotic shock in Tetraselmis marina, Picochlorum sp. and Dunaliella sp. CS was the most efficient method of lipid extraction in Amphora subtropica and Picochlorum sp. while BD and DT method in Tetraselmis marina and Dunaliella sp. Fatty acid analysis of all microalgae oil showed high level of SFA and MUFA, indicating a composition potentially useful for biodiesel production. The results of the present study revealed that the lipid content of the UV-treated microalgae was further significantly increased with the increase of carotenoid content, MDA level and antioxidants enzymes activities. The overall lipid contents of Amphora subtropica, Tetraselmis marina, Picochlorum sp. and Dunaliella sp. were increased to 54.7, $58.9,47.8$ and $63.4 \%$, respectively, a $1.5,1.8,2.1$ and 1.8-fold increase compared to control condition.

\section{Acknowledgment}

This study was supported by the Ministry of Higher Education and Scientific Research of Tunisia under the Contract Program of the Environmental Bioprocesses Laboratory.

\section{References}

1. Mata TM, Martins AA, Caetano NS (2010) Microalgae for biodiesel production and other applications : A review, Renew. Sust Energ Rev 14(1): 217-232.

2. Mendes RL, Nobre BP, Cardoso MT, Pereira AP, Palavra AF (2003) Supercritical carbon dioxide extraction of compounds with pharmaceutical importance from microalgae. Inorg Chim Acta 356: 328334.

3. Batista AP, Gouveia L, Bandarra NM, Franco JM, Raymundo A (2013) Comparison of microalgal biomass profiles as novel functional ingredient for food products. Algal Res 2(2): 164-173.
4. Chisti Y (2008) Biodiesel from microalgae beats bioethanol. Trends Biotechnol 26(3): 126-131.

5. Arumugam M, Agarwal A, Arya MC, Ahmed Z (2013) Influence of nitrogen sources on biomass productivity of microalgae Scenedesmus bijugatus. Bioresour Technol 131: 246-249.

6. Chen CY, Yeh KL, Aisyah R, Lee DJ, Chang JS (2011) Cultivation, photobioreactor design and harvesting of microalgae for biodiesel production: A critical review. Bioresour Technol 102(1): 71-81.

7. Keris Sen UD, Sen U, Soydemir G, Gurol MD (2014) An investigation of ultrasound effect on microalgal cell integrity and lipid extraction efficiency. Bioresour Technol 152: 407-413.

8. Kwietniewska E, Tys J (2014) Process characteristics, inhibition factors and methane yield of anaerobic digestion process, with particular focus on microalgal biomass fermentation. Renew Sust Energ Rev 34: 491500 .

9. Halim R, Harun R, Danquah MK, Webley PA (2012) Microalgal cell disruption for biofuel development. Appl Energ 91(1): 116-121.

10. Lee JY, Yoo C, Jun SY, Ahn CY, Oh HM (2010) Comparison of several methods for effective lipid extraction from microalgae. Bioresour Technol 101(1): 575-577.

11. Vieler A, Wilhelm C, Goss R, Süß R, Schiller J (2007) The lipid composition of the unicellular green alga Chlamydomonas reinhardtii and the diatom Cyclotella meneghiniana investigated by MALDI-TOF MS and TLC. Chem Phys lipids 150(2): 143-155.

12. Chen Y, Wang J, Liu T, Gao L (2012) Effects of initial population density (IPD) on growth and lipid composition of Nannochloropsis sp. J Appl Phycol 24(6): 1623-1627.

13. Liang Y, Beardall J, Heraud P (2006) Effects of nitrogen source and UV radiation on the growth, chlorophyll fluorescence and fatty acid composition of Phaeodactylum tricornutum and Chaetoceros muelleri (Bacillariophyceae). J Photochem Photobiol B Biology 82(3): 161-172.

14. Cheng CH, Dub TB, Pi HC, Jang MS, Lin HJ, et al. (2011) Comparative study of lipid extraction from microalgae by organic solvent and supercritical $\mathrm{CO}_{2}$. Bioresour Technol 102(21): 10151-10153.

15. Byreddy AR, Gupta A, Barrow CJ, Puri M (2015) Comparison of Cell Disruption Methods for Improving Lipid Extraction from Thraustochytrid Strains. Marine Drugs 13(8): 5111-5127.

16. Fang M, Jin M, Zhang C, Tan Y, Jiang P, et al. (2013) Rapid mutation of spirulina platensis by a new mutagenesis system of atmospheric and 
room temperature plasmas (ARTP) and generation of a mutant library with diverse phenotypes. In PLoS One 8: 1-12.

17. Zeeshan M, Prasad SM (2009) Differential response of growth, photosynthesis, antioxidant enzymes and lipid peroxidation to UV-B radiation in three cyanobacteria. South Afr J Botany 75(3): 466-474.

18. Singh SP, Häder DP, Sinha RP (2010) Cyanobacteria and ultraviolet radiation (UVR) stress: Mitigation strategies. Ageing Res Rev 9(2): 7990.

19. Sivaramakrishnan R, Incharoensakdi A (2017) Direct transesterification of Botryococcus sp. catalysed by immobilized lipase: Ultrasound treatment can reduce reaction time with high yield of methyl ester. Fuel 191: 363-370.

20. Lamers PP, Janssen M, De Vos RCH, Bino RJ, Wijffels RH (2012) Carotenoid and fatty acid metabolism in nitrogen-starved Dunaliella salina, a unicellular green microalga. J Biotechnol 162(1): 21-27.

21. Al Rashed SA, Ibrahim MM, El Gaaly GA, Al Shehri S, Mostafa A (2016) Evaluation of radical scavenging system in two microalgae in response to interactive stresses of UV-B radiation and nitrogen starvation. Saudi J Biological Sci 23(6): 706-712.

22. Rakhimberdieva MG, Stadnichuk IN, Elanskaya IV, Karapetyan NV (2004) Carotenoid induced quenching of the phycobilisome fluorescence in photosystem II deficient mutant of Synechocystis sp. FEBS letters 574(13): 85-88.

23. He YY, Häder DP (2002) Reactive oxygen species and UV-B: Effect on cyanobacteria. Photochem Photobiol Sci 1(10): 729-736.

24. Dahmen I, Chtourou H, Jebali A, Daassi D, Karray F, et al. (2014) Optimisation of the critical medium components for better growth of Picochlorum sp. and the role of stressful environments for higher lipid production. J Sci Food Agricult 94(8): 1628-1638.

25. Chtourou H, Dahmen I, Jebali A, Karray F, Hassairi I, et al. (2015) Characterization of Amphora sp., a newly isolated diatom wild strain, potentially usable for biodiesel production. Bioprocess Biosyst Eng 38(7): 1381-1392.

26. Dahmen Ben Moussa I, Chtourou H, Rezgui F, Sayadi S, Dhouib A (2016) Salinity stress increases lipid, secondary metabolites and enzyme activity in Amphora subtropica and Dunaliella sp. for biodiesel production. Bioresour Technol 218: 816-825.

27. Dahmen Ben Moussa I, Chtourou H, Karray F, Sayadi S, Dhouib A (2017) Nitrogen or phosphorus repletion strategies for enhancing lipid or carotenoid production from Tetraselmis marina. Bioresour Technol 238: 325-332.

28. Folch J, Lees M, Sloane Stanley GH (1957) A simple method for the isolation and purification of total lipids from animal tissues. J Biological Chemist 226(1): 497-509.

29. Bligh EG, Dyer WJ (1959) A rapid method of total lipid extraction and purification. Can J biochem physiol 37(8): 911-917.

30. Cequier Sànchez E, Rodríguez C, Ravelo ÀG, Zàrate R (2008) Dichloromethane as a solvent for lipid extraction and assessment of lipid classes and fatty acids from samples of different natures. J Agricult Food Chem 56(12): 4297-4303.

31. Lee SJ, Yoon BD, Oh HM (1998) Rapid method for the determination of lipid from the green alga Botryococcus braunii. Biotechnol Tech 12(7): 553-556.

32. Bigogno C, Khozin Goldberg I, Boussiba S, Vonshak A, Cohen Z (2002) Lipid and fatty acid composition of the green oleaginous alga Parietochloris incisa, the richest plant source of arachidonic acid. Phytochemistry 60(5): 497-503.

33. Hiscox JT, Israelstam G (1979) A method for the extraction of chlorophyll from leaf tissue without maceration. Can J botany 57(12): 1332-1334.
34. Draper HH, Hadley M (1990) Malondialdehyde determination as index of lipid peroxidation. Methods Enzymol 186: 421-431.

35. Flohe L, Gunzler WA (1984) Assays of glutathione peroxidase. Methods Enzymol 105: 114-121.

36. Wang D, Li Y, Hu X, Su W, Zhong M (2015) Combined enzymatic and mechanical cell disruption and lipid extraction of green alga Neochloris oleoabundans. Int J Mol Sci 16(4): 7707-7722.

37. Lardon L, Helias A, Sialve B, Steyer JP, Bernard O (2009) Life-cycle assessment of biodiesel production from microalgae. Environ Sci Technol 43(17): 6475-6481.

38. Widjaja A, Chien CC, Ju YH (2009) Study of increasing lipid production from fresh water microalgae Chlorella vulgaris. J Taiwan Instit Chem Eng 40(1): 13-20.

39. Yoo G, Park WK, Kim CW, Choi YE, Yang JW (2012) Direct lipid extraction from wet Chlamydomonas reinhardtii biomass using osmotic shock. Bioresour Technol 123: 717-722.

40. Rakesh S Dhar, DW Prasanna R, Saxena AK, Saha S, Shukla M, et al. (2015) Cell disruption methods for improving lipid extraction efficiency in unicellular microalgae. Engineer Life Sci 15: 443-447.

41. Kim J, Yoo G, Lee H, Lim J, Kim K, et al. (2013) Methods of downstream processing for the production of biodiesel from microalgae. Biotechnol Adv 31(6): 862-876.

42. Kar JR, Singhal RS (2014) Investigations on ideal mode of cell disruption in extremely halophilic Actinopolyspora halophila (MTCC 263) for efficient release of glycine betaine and trehalose. Biotechnol Rep 5: 8997.

43. Rashid U, Anwar F, Moser BR, Knothe G (2008) Moringa oleifera oil: a possible source of biodiesel. Bioresour Technol 99(17): 8175-8179.

44. Caprioli G, Giusti F, Ballini R, Sagratini G, Vila Donat P, et al. (2016) Lipid nutritional value of legumes: Evaluation of different extraction methods and determination of fatty acid composition. Food chem 192: 965-971.

45. Kumar M, Kumari P, Trivedi N, Shukla MK, Gupta V, et al. (2011) Minerals, PUFAs and antioxidant properties of some tropical seaweeds from Saurashtra coast of India. J Appl Phycol 23(5): 797-810.

46. Sinha RP, Häder DP (2002) Life under solar UV radiation in aquatic organisms. Adv Space Res 30(6): 1547-1556.

47. Ranjbarfordoei A, Samson R, Van Damme P (2011) Photosynthesis performance in sweet almond [Prunus dulcis (Mill) D. Webb] exposed to supplemental UV-B radiation. Photosynthetica 49: 107-111.

48. Jiang H, Qiu B (2011) Inhibition of photosynthesis by UV-B exposure and its repair in the bloom-forming cyanobacterium Microcystis aeruginosa. J Appl Phycol 23(4): 691-696.

49. Zhang X, Tang X, Zhou B, Hu S, Wang Y (2015) Effect of enhanced UV-B radiation on photosynthetic characteristics of marine microalgae Dunaliella salina (Chlorophyta, Chlorophyceae). J Exp Marine Biol Ecol 469: 27-35.

50. Sendra M, Sánchez Quiles D, Blasco J, Moreno Garrido I, Lubián LM, et al. (2017) Effects of $\mathrm{TiO}_{2}$ nanoparticles and sunscreens on coastal marine microalgae: Ultraviolet radiation is key variable for toxicity assessment. Env internat 98: 62-68.

51. Ahmed F, Fanning K, Netzel M, Turner W, Li Y, et al. (2014) Profiling of carotenoids and antioxidant capacity of microalgae from subtropical coastal and brackish waters. Food Chem 165: 300-306.

52. Lamers PP, van de Laak CC, Kaasenbrood PS, Lorier J, Janssen M, et al. (2010) Carotenoid and fatty acid metabolism in light stressed Dunaliella salina. Biotechnol bioeng 106(4): 638-648.

53. Guihéneuf F, Fouqueray M, Mimouni V, Ulmann L, Jacquette B, et al. (2010) Effect of UV stress on the fatty acid and lipid class composition in 
two marine microalgae Pavlova lutheri (Pavlovophyceae) and Odontella aurita (Bacillariophyceae). J Appl Phycol 22(5): 629-638.

54. Casazza AA, Ferrari PF, Aliakbariana B, Converti A, Peregoa P (2015) Effect of UV radiation or titanium dioxide on polyphenol and lipid contents of Arthrospira (Spirulina) platensis. Algal Res 12: 308-315.

55. Aebi H (1984) Catalase in vitro. Meth Enzymol 105: 121-126.

ISSN: 2574-1241

DOI: 10.26717/BJSTR.2018.09.001813

Ines Dahmen Ben Moussa. Biomed J Sci \& Tech Res

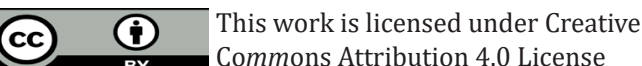

Submission Link: https://biomedres.us/submit-manuscript.php
56. McMillan JR, Watson IA, Ali M, Jaafar W (2013) Evaluation and comparison of algal cell disruption methods: Microwave, waterbath, blender, ultrasonic and laser treatment. Appl Energ 103: 128-134.

57. Tran DT, Chen CL, Chang JS (2013) Effect of solvents and oil content on direct transesterification of wet oil-bearing microalgal biomass of Chlorella vulgaris ESP-31 for biodiesel synthesis using immobilized lipase as the biocatalyst. Bioresour Technol 135: 213-221.

$\begin{array}{ll}\text { BIOMEDICAL } & \text { Assets of Publishing with us } \\ \text { RESEARCHES } & \text { - Global archiving of articles } \\ & \text { - Immediate, unrestricted online access } \\ & \text { - Rigorous Peer Review Process } \\ \end{array}$

